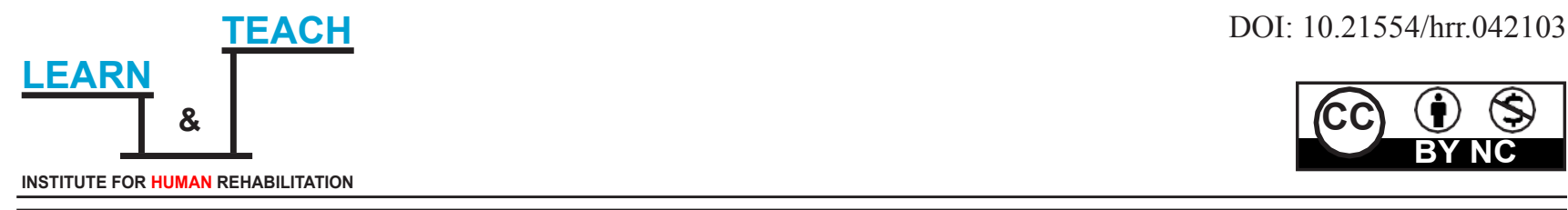

\title{
FEAR IN MATHEMATICS TEACHING AMONG PRIMARY SCHOOL STUDENTS
}

Original scientific paper

\author{
Sead Resic ${ }^{1}$, Maid Omerovic ${ }^{2}$, Ahmed Palic ${ }^{2}$ \\ ${ }^{1}$ Department of Mathematics, Faculty of Science, University of Tuzla, Bosnia and Herzegovina \\ ${ }^{2}$ Faculty of Education, University of Travnik, Bosnia and Herzegovina
}

Received: $2021 / 2 / 3$

Accepted: 2021/3/27

\begin{abstract}
The aim of this work is toresearch does exist a fear of mathematics, what are the causes offear of mathematics, in what forms fear is manifested and what parents do to repress a fear of mathematics at students in higher grades of elementary school. For the purposes of the research, two separate scales were created which measured the fear of mathematics at students from the perspective of parents and students. The research was conducted in the elementary schools in Central Bosnia with students of fifth, sixth, seventh, eighth and ninth grades. We leave the survey questionnaire at the end, in attachment, so that it can be viewed. Analysis or data processing we worked and we got results which we've presented in this work. There shouldn't be fear in the teaching process. Students shouldn't come to school under pressure or in fear, but should find ways to motivate themselves to work because of their personal progress and training for life. Parents and teachers help them with that. Achievements in mathematics are researched more than achievements in other subjects because mathematics is important for researching and comparing different educational systems.Because of this importance, we need to find ways to repress the students 'fear of math.Students, except motivation for working, should give encouragement and support. Communication with the child, and communication in the parent-school-student relationship is very important in repressing the child's fear. Keywords: fear, mathematics (math), student, elementary school
\end{abstract}

\section{INTRODUCTION}

Mathematics is not just a school subject, it is our daily habit that we face every day, so it is very important how students will accept mathematics as a school subject. Today, mathematics is taught to students in primary and secondary schools, as well as at numerous faculties. We will base our research on mathematics as a school subject in primary school. When they remember mathematics from primary school, some students remember with discomfort, and individuals blush, their palms sweat, their hearts beat faster. They wonder why all these feelings, because they do not need a lot of teaching materials that they learned during primary school in the continuation of life. Other students have different thoughts and think that mathematics is an understandable and useful science.Students in the school are not even aware that mathematics has always been and will be one of the most important subjects. Why? Because success in this society largely depends on the ability to professionally use mathematical actions and skills. Applying math is everyday from winding up a lesson that reminds us of going to school, to work to compiling a family budget based on monthly income.

Correspondence to:

Sead Resic, Department of Mathematics, Faculty of Science, University of Tuzla, Bosnia and Herzegovina

Univerzitetska 4, 75000 Tuzla, Bosnia and Herzegovina

Phone:+38761 101230

E-mail: sresic@hotmail.com 
When we talk about mathematics in our country, it is generally accepted that mathematics is difficult for students and that it creates fear in them and they have great stress from mathematics as a school subject. This fear, called mathematical anxiety, was previously described and examined, along with the remaining factors, in this paper.Parents and teachers have an important role in mastering the teaching content. From the first meeting with the school, they should work closely together to solve problems at the outset, if any. And what if there is a fear of school? What if there is a fear of math? What are we to do? How to suppress it? What are the causes of all of the above? In this paper, I will answer the questions of whether there is a fear of mathematics, what are the causes of fear of mathematics, in what forms fear is manifested and what parents do to suppress the fear of mathematics in students.

The importance of mathematical education and the historical development of mathematical ideas

Mathematics occupies a special place in the system of science "in that it does not deal with any specific matter but with relations in themselves, abstracted from the material basis-toreturn tothisinthephaseofapplication" (Printer, Petrovic, Sotirovic, \& Lipovac, 1996, p. 9). The application of mathematics in other sciences gives these sciences certainty. The subject of study in mathematics are those characteristics of relations between phenomena in the material world that do not depend on the specific nature of phenomena and conclusions that can be drawn logically in such a view of relations. Mathematics arose during concrete problems in the real world through mathematical modeling. Numerous documents tell us that the skill of computation has been studied since ancient times. An example is clay tablets found in the temple of God Baal in Ni Ppur on which are imprinted signs representing symbols of numbers and arithmetic operations. Numerous instructions on how to perform arithmetic operations have been found on Egyptian monuments and papyri. The Egyptians and Romans had aids to calculate, the so-called. ABAK (plate with vertical grooves in which there were movable stones). It was calculated orally, not in writing as it is today. Instrumental calculus was also nurtured in the Middle Ages. In the history of mathematics and the history of human culture, a great advance has been made by introducing systems into positional computation. Computer rules are memorized without understanding. The credit for the introduction of positional calculus belongs to Adam Ries (1492-1559). In the 17th century, mathematics was introduced in primary schools as a compulsory subject. The basis of the methodology of teaching arithmetic was mechanical learning of rules and mnemonic - technical procedures. In the first half of the 18th century, the rule according to the rules prevailed, and the main representative was Kristijan Pesek (Christian Pescheck). In the second half of the 18th century, the formal goal of teaching mathematics was emphasized (logical calculation was approached, and the aim was to strengthen and develop mental functions).Methodists Busse and Rochow, as well as Heinrich Pestalozzi, made greatcontributions in this field.According to Pastalozzi's thinking, numbers are the best means of developing psychic powers, and Zor is the absolute foundation of all cognition. He introduces the teaching of arithmetic. Radical changes in the teaching of mathematics in secondary and primary school were hinted at by the Meran conferences held in 1905 in Merano. The teaching of mathematics tried to get closer to the life and interests of the students. J. Kinel (Kuhnel), Weber (Weber), psychologists Wittman and J. Piaget made a great contribution to the improvement of mathematics teaching. At the beginning of the 20th century, laboratory teaching, ie polytechnic teaching, was represented, where the teaching of mathematics was practically emphasized. In the second half of the twentieth century, the opposite direction to practicality emerged, "modern mathematics", which put formalism, abstractness and logic in the forefront.

\section{Fear}

Emotions play a central role in an individual's life. They are primary experiences that occur before all others in the development of a living being and, although we know what is meant by the term emotion (experiences caused by an external or internal situation, characterized by the fact that they are mostly pleasant or unpleasant, and sometimes ambivalent) a term in psychology so undefined (Petz, 1992). In the broadest sense, emotions can be defined as an excited state of the organism that manifests itself in several ways: by physiological arousal or activation; cognitive interpretation or assessment; external signs or expression; by behavior or reaction. According to the degree of complexity, we divide them into:

The primary emotions that we find in all cultures and in all people, and are manifested in the characteristic facial expression that is universally recognizable. Such emotions are: joy, sorrow, anger and fear. Secondary emotions are assemblies of different emotions or cultural variations of emotional experiences. While primary emotions appear very early in individual development, complex emotions such as jealousy require a certain level of development of cognitive processes and the ability to perceive interpersonal relationships, so they occur somewhat later in the development of children. While joy and anger are in a sense "emotions of approach," fear is the opposite of "emotions of avoidance". It is characterized by escape from danger. An essential characteristic of a situation in which fear occurs is the perception of a dangerous object or threat, and the crucial here is the perception of a lack of power or ability for an individual to fight danger. An important component of many situations in which fear occurs is a time perspective facing the future. 
Namely, the individual predicts what will happen in the future, and keeping thoughts on these events creates states of strong anticipatory fear. It is this anticipation of impending danger that is usually perceived as anxiety - a complex and uncomfortable feeling of anxiety, fear, tension and insecurity, accompanied by activation of the autonomic nervous system. We distinguish it from fear in that fear is a "more concrete" emotion (Arambashi, 1988), ie the person who is afraid usually knows what he is afraid of. The term itself was introduced into psychology by Freud in 1894, describing anxiety neurosis, and in modern psychology the term is used to describe emotional reactions caused by unknown and / or unrecognizable causes, but also for emotional states aroused by real or predictable danger. Like other emotional reactions, anxiety has a motivating effect. Thus, moderate levels of anxiety often have a positive effect on performance in many activities, while extremes such as complete absence or very intense anxiety can visibly reduce an individual's performance in some activities. (Agic \& Resic, 2011) Fear is a feeling that a person has when he assesses that he is endangered or some of its value, without being able to adequately oppose the object or situation that threatens him. Fears are an integral part of childhood. It is estimated that over $90 \%$ of children aged 2 to 14 have at least one specific fear, and most have multiple fears. Intense and long-lasting fears in childhood have been shown to be the strongest vulnerability factor for the development of anxiety disorders in adolescence. Fear and anxiety occur on a continuum from normal, common, in intensity and duration, all the way to various anxiety disorders. Thus the fear of unclean objects can turn into an obsessive-compulsive disorder. When we talk about childhood fears, different authors cite different classifications of children's fears. Children's fears are defined as reactions to a perceived threat that include avoiding the object or situation that is causing the threat, subjective feelings of discomfort, and physiological activation. If the perceived danger, that is, the threat, is real, we speak of fear, and if the danger is objectively non-existent and if the experience of danger is anticipatory, we speak of anxiety. Therefore, anxiety is the fear of situations that have not yet occurred. It is about the fear that something bad will happen. Authors Berce and Lepuvscek (2011) divide children's fears into four categories:

1. social fears (fear of strangers, fear of meeting new people, etc.),

2. specific fears or phobias (fear of darkness, water, animals, etc.),

3. agoraphobic fears (fear of exposure to situations such as elevators, bridges, crowds, loneliness, etc.) and

4. multiple fears, which represent a combination of several previously mentioned fears
Fear of school also occurs in children whose parents have very high expectations and in the best of intentions tell the children: "You will certainly be very good, you will have all fives, everyone will admire you." The child's desire to meet the expectations of his parents leads the child to fear of failure, and that he will disappoint his parents if he is not successful in school, which causes various difficulties in which parents do not recognize the fear of school. Fear of school also occurs in children growing up in families in which parents are overprotective (often because of their separation fears). Fear of school often occurs in children growing up in a family where family dynamics are disrupted (eg parental divorce, intense conflict, parental illness) so that the child rejects school because he or she needs to "control the new, unfavorable family situation and thus prevent disintegration. families." Very often the fear of school is a consequence of the child's exposure to physical and verbal peer violence, on the way to school or at school, but also, for example, isolation from other students in the class, difficulties in establishing social contacts. "Using factor analysis, fears can be grouped into the following categories:

1. fear of failure and criticism,

2. fear of the unknown,

3. fear of injury and small animals,

4. fear of danger and death,

5. fear of medical procedures "(Koludrovic \& Radnic, 2013, p. 65).

\section{Phobias}

The term phobia derives from the Greek word phobos meaning fear, escape. Phobia is a strong, irrational, lasting fear of certain situations, objects, activities, people; exaggerated perception of impending danger associated with a specific situation or specific object. Milivojevic (2007) states that the basic symptoms of phobia are considered to be a strong, constant, uncontrollable conscious desire to avoid a certain unpleasant situation and a whole range of physical manifestations such as redness, trembling, dry mouth, sweating palms, increased desire to urinate, urinate, palpitations (feeling of rapid or irregular heartbeat) and panic attacks. It is important to understand and draw the line between phobia and fear. Fear is a normal and expected reaction to a threat from the environment. It is essential for survival because it warns us that circumstances can be physically or mentally dangerous. Phobia differs from fear in its intensity, which is much higher than expected, and differs in maladaptation and duration. Phobias are beyond the control of our will. Psychopathologists believe that a phobia is actually an avoidance that interrupts the normal course of life, and is disproportionate to the actual danger of an object or situation. Most often, the phobic person himself notices that this fear is unfounded. 
Born (2008) states that the symptoms of a phobic disorder include the following:

1. The victim suddenly feels irrational and lasting fear, panic, horror when he finds himself in a certain situation that is not otherwise threatening.

2. A phobic person is otherwise aware that his fear exceeds the limits of the normal and that there is no real danger.

3. The phobic reaction is automatic, pervasive. A person cannot control it, and practically everyone is obsessed with the imagination of threat and danger.

4. A phobic person shows all the bodily reactions present in great fear: rapid heartbeat, feeling short of breath, shallow breathing, trembling, and a strong desire to escape from a phobic situation.

5. A phobic person avoids objects and situations that he is afraid of and deviates from the normal or usual path in order to avoid them.

Phobias can be divided into: phobias from social activities and situations (social phobia) and specific, ie isolated phobias (fear of one particular type of object or situation). Specific phobias represent intense fear and avoidance of one particular type of object or situation. Fear and avoidance are strong enough to disrupt daily routine, work, or relationships and cause significant mental suffering. Although phobia involves avoiding a particular object or situation, there is often an interrelationship between phobia of social activities and phobia of certain situations or objects. This is exactly the case we have with children who have a school phobia and a phobia of mathematics.

\section{Metaphobia}

School phobia is a child's resistance to going to school due to intense fear. The child apparently wants to go to school, but manifests a series of physical manifestations that mislead parents and the environment, so parents look for the cause in a physical problem instead of a psychological one. This is a fear that usually occurs at the age when the demands and expectations of children increase (in primary school in the first, second and sixth grade, and in secondary school at the beginning of the first grade), but this does not have to be the rule because fear can arise later as a result some unpleasant experiences. Metaphobia manifests itself as a fear of mathematics. A person who has a fear of math avoids contact with math in situations that have to do with math. The range of symptoms ranges from a feeling of mild discomfort when encountering quantitative information to complete avoidance of anything resembling mathematics. The causes of mathematical phobia lie in the child's first encounters with mathematics and the first difficulties that arise. There can be several patterns of such difficulties: cognitive immaturity, insufficient readiness, too high expectations, poor teaching methods, etc. Metaphobia manifests itself in two forms, specific and general metaphobia.
A student with a specific metaphobia does not offer resistance to mathematics in general, but only in certain areas of mathematics. This form of fear arises due to certain, specific situations related to mathematics. For some reason, a specific mathematical area creates a mental block in the process of adopting new mathematical concepts or in repeating learned material. Sharma (2001) states, students who are afraid of anything to do with mathematics have a general metaphobia. These students are usually equally unsuccessful in all subjects, but as precise answers are sought in math classes, which students do not encounter in other subjects, this makes the fear more intense. People with this form of fear have difficulties in all areas of mathematics, so their reaction is general.

\section{RESEARCH METHODOLOGY}

\section{Research problem}

The topic is interesting to research given that math is a ghost subject all over the world. It records the lowest success compared to other subjects. Mathematics is interdisciplinary, it occurs in other disciplines. As a subject, it occupies a very important place in all programs. The significance of this research work is that we will reach new results that will enable us to improve the educational work in the teaching of mathematics.

\section{Subject of research}

We can look for the fear of mathematics in the first inconveniences and failures that children experience when they encounter mathematics. And there should be no fear in teaching. The subject of the research is the extent to which fear occurs in students, and what are the ways to suppress the fear of mathematics.

\section{Research goal}

The aim of the research is to investigate whether there is a fear of mathematics, what are the causes of fear of mathematics, in what forms fear is manifested and what parents and teachers do to suppress the fear of mathematics in subject students.

\section{Research tasks}

Based on a certain goal of the research, the research tasks were left, as follows: 1. Examine whether there is a fear of mathematics in upper elementary school students.

2. Examine the causes of fear of mathematics in upper elementary school students.

3. Examine the forms in which the fear of mathematics is manifested in students in the upper grades of primary school.

4. Examine whether there is a difference in fear of mathematics in boys and girls in the upper grades of primary school. 
5. Examine what parents do to suppress the fear of mathematics in students in upper elementary school students.

\section{General hypotheses}

Main hypothesis: There is a fear of mathematics among upper elementary school students.

Subhypothesis $\mathbf{1}$ : There is no statistically significant difference with respect to the demographic characteristics of the parents.

Subhypothesis 2: There is no statistically significant difference in the perception of fear of mathematics in students with respect to the demographic characteristics in the child.

Subhypothesis 3: There is no statistically significant difference between boys and girls in the amount of fear of mathematics.

Subhypothesis 4 : There is no statistically significant difference with respect to class in the amount of fear of mathematics.

\section{Research variables}

In order to obtain the most accurate data in the research, dependent and independent variables were determined. Dependent variables are the characteristics of the phenomena that interest us most in research, so we bring this variable in connection with other variables that describe or explain it. And variables that describe or explain a dependent variable are called independent variables. The dependent variable is always in the research problem (Vujevic, 2006).

\section{Research methods}

The descriptive method, the method of theoretical analysis, the comparative method and the Survey method were used in the research. Descriptive method-is a source of essentialknowledge about the nature of the studied subjects, the possibility of developing a particular situation from one interval to another, so that the researcher can plan and predict future actions and interventions (Halmi, 2003). In this research paper, the descriptive method was used in describing and interpreting the research results. The method of theoretical analysis-involves the use of pedagogical-psychological literature, manuals, textbooks, professional and scientific papers, encyclopedias and allows to study new sources and scientific conclusions afterstudying sources, collected facts and analyzed connections and relationships, studied objects and phenomena (Muzic, 1986). This method was used in the study of the literature that was needed for the theoretical settings of this research. Comparative method - involves comparing the same or similar facts, phenomena, processes and relationships, and determines their similarities in behavior and intensity, as well as differences between them (Muzic, 1986).
This method was used to compare the obtained results of the student survey and the parent survey in order to draw conclusions in accordance with the set goal and objectives of the research. Survey method - allows the application of various measurement instruments and a variety of data processing procedures (Halmi, 2003). The Likert scale was used in this study. It is a kind of scale of attitudes that consists of a series of statements dedicated to different aspects of an attitude.

\section{Research techniques}

Survey were used as a research technique. Students and parents were interviewed. Interviewing is a procedure by which respondents respond in writing to questions related to facts that are known to them or to questions related to their personal opinion (Muzic, 1999). The importance of this procedure lies in the fact that often only a poll can provide the required data, and that it is much more economical than interviewing.

\section{Research instruments}

For the purposes of the research, two separate scales were created which measured the fear of mathematics in students from the perspective of parents and students. Scales for parents and students were originally created with 30 questions each. However, after a preliminary analysis of the scales, certain issues are excluded because their parameters are not satisfactory and thus impair the reliability of the entire scale. The scale for parents in final form has 27 questions, and satisfactory reliability from Crombach $\alpha=.74$. The scale for students consists of 19 questions, and the reliability of the scale is Crombach $\alpha=.73$.

\section{Table 1. Crombach reliability coefficient of the scale}

\begin{tabular}{ccc}
\hline & Reliability (a) & $\begin{array}{c}\text { Number } \\
\text { of particles }\end{array}$ \\
\hline Scale for parents & .74 & 27 \\
Scale for students & .73 & 19 \\
\hline
\end{tabular}

Both scales are Likert-type scales with 5 degrees and the results on both scales were obtained as the arithmetic mean of the answers to all questions that fall within the scale with the aim of easier interpretation of the results in relation to other groups. A higher score represents a higher perceived level of fear in students. It is important to emphasize that the results of these two scales are not mutually comparable. The questionnaire for students contains two open-ended questions in which it was necessary to describe situations in which one feels fear of mathematics and how that fear manifested itself. The parent/guardian questionnaire contained three open-ended questions to describe situations in which fear of mathematics was felt, how the fear manifested itself, and how parents suppressed their child's fear of mathematics. 


\section{Sample research}

The research sample consists of fifth, sixth, seventh, eighth and ninth grade elementary school students in Central Bosnia and their parents.

\section{Students}

The sample of students is the largest sample in the study with a total of $\mathrm{N}=104$ respondents, of which $44.30 \%$ $(\mathrm{n}=46)$ are boys and $55.70 \%(\mathrm{n}=58)$ are girls. The distribution by classes is relatively even. The largest number of students attends the sixth grade $(22.11 \%)$, followed by the fifth grade $(20.19 \%)$, followed by the seventh, eighth and ninth grade with the same number of students $(19.23 \%)$.

Table 2. Gender of students

\begin{tabular}{ccc}
\hline Gender & f & $\%$ \\
\hline Boys & 46 & 44.30 \\
Girls & 58 & 55.70 \\
\hline Total & 104 & 100.00 \\
\hline
\end{tabular}

Table 3. The class that students attend

\begin{tabular}{ccc}
\hline Class & f & $\%$ \\
\hline V & 21 & 20.19 \\
VI & 23 & 22.11 \\
VII & 20 & 19.23 \\
VIII & 20 & 19.23 \\
IX & 20 & 19.23 \\
\hline Total & 104 & 100.00 \\
\hline
\end{tabular}

\section{Parents}

The sample of parents included $\mathrm{N}=68$ respondents whose children attend subject classes in mathematics. Of these, $29.41 \%(\mathrm{n}=20)$ were fathers, and $67.64 \%$ $(\mathrm{n}=46)$ were mothers who participated in the study.
The study also included $\mathrm{n}=2$ tutors.Most parents have completed higher education (63.23\%), and $35.29 \%$ of parents have a high school diploma. About two-thirds of parents are aged 36-45 (61.76\%). $27.94 \%$ of parents belong to the age group of $46-56$ years, while $10.29 \%$ of them belong to the group of 25-35 years. $89.71 \%$ of parents state that they are employed, while $10.2 \%$ are unemployed.

The distribution of classes attended by the children of the parents included in the research is even.

Table 4. Parents/Tutors completing the questionnaire

\begin{tabular}{|c|c|c|}
\hline Parents & f & \% \\
\hline Father & 20 & 29.41 \\
Mother & 46 & 67.64 \\
\hline Tutor & 2 & 2.94 \\
\hline Total & 68 & 100.00 \\
\hline
\end{tabular}

\section{Survey procedure and experiences}

The survey was conducted in November and December 2020. One class of V, VI, VII, VIII and IX grades was interviewed.

The application of the questionnaire was group, at once in the whole class in the classes of the class community. Each student received a survey questionnaire for themselves and for one parent. Students are asked to read the instructions carefully, and to be as honest as possible in their answers since the research is anonymous. The annexation lasted 20-25 minutes. During the survey, students were interested and motivated. They wondered if their math teachers would be able to see what they were writing. It was explained to them that the school pedagogue will receive the results of the research due to the improvement of teaching. When itcomestosurvey questionnaires forparents, about $34 \%$ of students did not return the survey questionnaire for parents. These $34 \%$ also include parents with more than two children included in the research sample.

\section{RESEARCH RESULTS}

Table 5. Descriptive indicators - survey questionnaire - STUDENTS

\begin{tabular}{|c|c|c|c|}
\hline & Mean & Std. Error & Std. Deviation \\
\hline I am happy to have 4 math classes a week & 2.85 & .13 & 1.33 \\
\hline When I enter the math classroom I feel fear & 2.22 & .12 & 1.23 \\
\hline Learning math is boring & 2.99 & .14 & 1.45 \\
\hline Some kids just aren't born for math and can never learn it. & 3.18 & .15 & 1.51 \\
\hline When I have to answer math I feel fear & 3.29 & .15 & 1.50 \\
\hline I'm not afraid to ask if something isn't clear to me. & 3.51 & .14 & 1.44 \\
\hline The teacher reviews the homework and points out mistakes, if any & 2.84 & .15 & 1.53 \\
\hline When I write important homework I feel fear & 1.82 & .12 & 1.20 \\
\hline The math is hard & 3.13 & .13 & 1.36 \\
\hline I don't understand basic mathematical phenomena & 2.47 & .13 & 1.31 \\
\hline A lot of the things I learn in math, I don't need out of school & 3.16 & .14 & 1.42 \\
\hline The math teacher explains in detail if something is not clear & 3.63 & .13 & 1.37 \\
\hline Homework makes it easier for me to learn math & 3.36 & .14 & 1.42 \\
\hline The math is interesting & 2.89 & .13 & 1.37 \\
\hline When I have written checks I feel fear & 3.19 & .15 & 1.57 \\
\hline
\end{tabular}


Continuation of the Table 5. Descriptive indicators - survey questionnaire - STUDENTS

\begin{tabular}{|c|c|c|c|}
\hline & Mean & Std. Error & Std. Deviation \\
\hline I prefer oral answering to written task solving & 3.00 & .14 & 1.44 \\
\hline I am happy when we practice arithmetic / problem solving with arithmetic operations & 2.99 & .13 & 1.36 \\
\hline I am happy when we practice text assignments & 2.31 & .14 & 1.40 \\
\hline I am happy when we practice geometry & 3.05 & .16 & 1.62 \\
\hline I am happy when we practice algebra & 2.77 & .14 & 1.46 \\
\hline In math class, I feel lost & 2.39 & .14 & 1.39 \\
\hline I spend at least 5 hours a week practicing math & 2.29 & .13 & 1.28 \\
\hline When I talk to my friends about math I feel fear & 1.82 & .12 & 1.19 \\
\hline Parents / Tutors expect me to know a lot more & 3.16 & .15 & 1.51 \\
\hline When I hear the word math, I don't feel comfortable & 2.35 & .14 & 1.47 \\
\hline Out of fear, I experience a blockade when it rings for the start of class & 2.26 & .14 & 1.46 \\
\hline When I answer, my palms sweat, my mouth is dry, my heart beats fast. & 3.12 & .15 & 1.57 \\
\hline When I have an announced test, I don't come to school & 1.46 & .09 & .89 \\
\hline When a teacher mentions math in BHS language, history and geography classes, I feel uneasy. & 2.14 & .14 & 1.39 \\
\hline My parents find math very difficult & 2.26 & .13 & 1.29 \\
\hline
\end{tabular}

By looking at Table 5, which shows the descriptive indicators obtained by the research, we can state the following important facts. Namely, the question "Teacher of Mathematics explains in detail if something is not clear" is the largest arithmetic mean of 3.63, while the largest deviation from the arithmetic mean, ie the standard deviation is recorded on the question
"I am happy when I practice geometry" and it is 1.62 . Furthermore, by looking at the above table, it can be concluded that the least arithmetic mean was recorded on the question that reads "When I have the announced test, I do not come to school" and the same is 1.46. Also, which is very interesting on the same issue, the smallest deviation from the arithmetic mean is recorded - .89.

Table 6. Descriptive indicators - survey questionnaire - PARENTS

\begin{tabular}{|c|c|c|c|}
\hline & Mean & Std. Error & Std. Deviation \\
\hline My child loves math & 3.49 & .14 & 1.13 \\
\hline My child solves math homework with ease & 3.53 & .13 & 1.09 \\
\hline My child feels fear when it comes to math & 2.85 & .16 & 1.32 \\
\hline My child feels fear when he asks what is not clear to him & 2.24 & .15 & 1.25 \\
\hline My child does not feel comfortable when math is mentioned & 2.04 & .13 & 1.03 \\
\hline My child has difficulty learning other subjects where math is mentioned & 1.85 & .12 & 1.00 \\
\hline My child feels fear when he has written checks & 2.91 & .16 & 1.29 \\
\hline My child prefers oral answers to written assignments & 3.01 & .16 & 1.29 \\
\hline My child feels fear of math not of teachers & 2.16 & .13 & 1.09 \\
\hline My child spends 5 hours a week practicing math & 2.40 & .14 & 1.14 \\
\hline My child talks about math with a smile & 2.85 & .13 & 1.06 \\
\hline As a parent / tutor, I find math very difficult & 2.53 & .15 & 1.24 \\
\hline As a parent, I think that a lot is required of children in teaching mathematics & 2.69 & .16 & 1.28 \\
\hline I practice math with my child every day & 2.51 & .13 & 1.09 \\
\hline My child feels afraid to ask me for help in learning math & 1.62 & .11 & .92 \\
\hline The math teacher is pleasant, professional, cheerful and understandable & 3.84 & .13 & 1.08 \\
\hline A math teacher does his job well & 3.76 & .13 & 1.07 \\
\hline I talk to my child about math & 3.47 & .11 & .91 \\
\hline I expect my child to know more about math & 3.57 & .12 & .98 \\
\hline I expect my child to have a better grade in math & 3.12 & .16 & 1.30 \\
\hline Fear of math arises because children do not learn regularly & 3.69 & .14 & 1.12 \\
\hline I think math needs talent & 2.49 & .13 & 1.06 \\
\hline Math takes a lot of time to learn & 2.60 & .12 & .98 \\
\hline As a child, I also felt a fear of math & 2.34 & .15 & 1.22 \\
\hline Conversation can prevent fear of math & 3.71 & .12 & .95 \\
\hline Exercising tasks can prevent fear of math & 4.04 & .12 & .97 \\
\hline More additional classes free children from the fear of mathematics & 3.68 & .13 & 1.03 \\
\hline Talking to a math teacher has a positive effect on the child & 3.97 & .12 & .98 \\
\hline More homework suppresses the fear of math & 3.15 & .14 & 1.14 \\
\hline Correlation / Relationship of mathematics with other subjects has a positive effect on the child & 3.49 & .14 & 1.14 \\
\hline
\end{tabular}


Table 6 shows us very important descriptive indicators, which, among other things, reflect the opinion and attitudes of parents about their children's fear of mathematics. If we look at the arithmetic mean, we see that the largest question is "Talking to a teacher about mathematics has a positive effect on the child" and it is 3.97, while the largest deviation from it was recorded on the question "My child feels fear when it comes to answering math", and the same 1.32 th most common. Insight into the mentioned Table also shows that the smallest arithmetic mean was recorded on the question that reads "My child feels afraid to ask me for help in learning mathematics" and it is 1.62 , while the smallest standard deviation was recorded on the question "With his I talk to my child about mathematics"whose value is .91. Based on the descriptive indicators presented, it can be slowly seen that fear in children exists and is expressed, which will be expressed below through sub-hypotheses and tests that imply the same.

Subhypothesis 1: There is no statistically significant difference with respect to the demographic characteristics of the parent sample From the table 7 , which shows the results of the $t$ test for all variables with two levels, we see that there is no statistically significant difference in the perception of fear of mathematics regardless of parental sex, child sex or parental employment, and thus our subhypothesis as such and confirmed. That is, both fathers and mothers have equal results when it comes to the perceived fear of mathematics in their children, and the same is true for male and female children, and the same result is obtained for employed and unemployed parents.

Table 7. $t$-test for differences in students' perception of fear of mathematics with respect to the demographic characteristics of the parent sample

\begin{tabular}{|c|c|c|c|c|c|c|c|}
\hline Variable & Group & $\mathbf{N}$ & $\mathbf{M}$ & SD & t-test & df & $p$ \\
\hline \multirow{2}{*}{ Parent } & Father & 20 & 2.84 & 1.108 & \multirow{2}{*}{-.67} & \multirow{2}{*}{64} & \multirow{2}{*}{-.79} \\
\hline & Mother & 46 & 3.04 & 1.09 & & & \\
\hline \multirow{2}{*}{$\begin{array}{l}\text { The sex of } \\
\text { the child }\end{array}$} & Male & 24 & 2.94 & 1.05 & \multirow{2}{*}{-.25} & \multirow{2}{*}{66} & \multirow{2}{*}{-1.23} \\
\hline & Female & 44 & 3.01 & 1.12 & & & \\
\hline \multirow{2}{*}{$\begin{array}{l}\text { Working } \\
\text { status }\end{array}$} & Employed & 61 & 2.96 & 1.116 & \multirow{2}{*}{-.56} & \multirow{2}{*}{66} & \multirow{2}{*}{-1.14} \\
\hline & Unemployed & 7 & 3.22 & .933 & & & \\
\hline
\end{tabular}

Table 8 presents the remaining analyzes on variables containing more than two independent groups. The ANOVA test showed that there are no statistically significant differences in the perception of fear of mathematics in parents with respect to demographic differences.
Subhypothesis 2: There are no statistically significant differences in the perception of fear of mathematics in students with regard to the demographic characteristics of the child sample.

Table 8. ANOVA test for differences in the perception of fear of mathematics in students with regardon the demographic characteristics of the child sample

\begin{tabular}{|c|c|c|c|c|c|c|c|}
\hline Variable & Group & $\mathbf{N}$ & $\mathbf{M}$ & SD & $\mathbf{F}$ & df & $p$ \\
\hline \multirow{3}{*}{ Education } & Elem. & 1 & 2.16 & & \multirow{3}{*}{1.18} & \multirow{3}{*}{2,66} & \multirow{3}{*}{.52} \\
\hline & High & 24 & 3.07 & 1.05 & & & \\
\hline & Higher & 43 & 2.98 & 1.08 & & & \\
\hline \multirow{3}{*}{ Age } & $25-35$ & 7 & 3.16 & 1.136 & \multirow{3}{*}{1.11} & \multirow{3}{*}{2,65} & \multirow{3}{*}{.46} \\
\hline & $36-45$ & 42 & 3.02 & 1.09 & & & \\
\hline & $46-56$ & 19 & 2.82 & 1.09 & & & \\
\hline \multirow{5}{*}{ Class } & $\mathrm{V}$ & 15 & 2.89 & 1.144 & \multirow{5}{*}{1.59} & \multirow{5}{*}{4,63} & \multirow{5}{*}{.50} \\
\hline & VI & 20 & 3.16 & 1.01 & & & \\
\hline & VII & 14 & 2.76 & 1.134 & & & \\
\hline & VIII & 16 & 3.05 & 1.04 & & & \\
\hline & IX & 3 & 3.05 & .77 & & & \\
\hline
\end{tabular}

In the following, the situations in which the fear of mathematics occurs, the ways in which this fear is manifested in students and the ways in which parents suppress their fear of mathematics are analyzed. About
$50 \%$ of parents did not give answers to these questions, so it is difficult to generalize the conclusion. The answer was most often given by parents who perceived a higher amount of fear of mathematics in their children. 
The answers are divided into several categories for easier analysis of the results. Graphs 1, 2, and 3 show the frequencies of coded responses. From Graph 1 we see that the fear of mathematics in students most often occurs in the case when both oral and written tests, about $60 \%$, if the case is only oral tests $18 \%$, written tests $15 \%$, while $7 \%$ of the answers stated some other reason for the appearance of fear, first of all a bad grade or fear of not meeting the expectations of the parents.

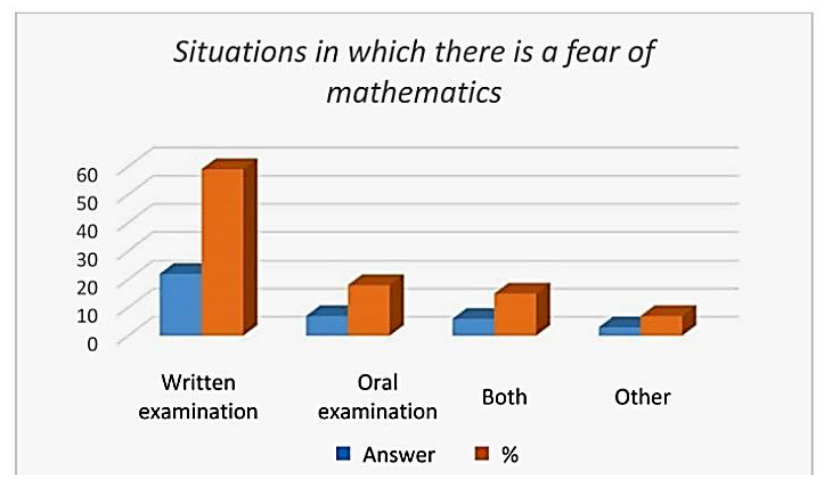

Graph 1. Situations in which there is a fear of mathematics

Graph 2 shows the form of the manifestation of fear. According to the answers of the parents, in most children, this fear is manifested through psychological symptoms, nervousness, blockage, confusion and similar behaviors, in $30 \%$ of them. $15 \%$ of parents' answers say that fear is manifested in students through physical symptoms, trembling, sweating, rapid heartbeat, while $8 \%$ of parents state other types of manifestation, most often crying.

Subhypothesis 3: There is no statistically significant difference between boys and girls in the amount of fear of mathematics. The results of students, similar to the previous results of teachers and parents, were analyzed with regard to the

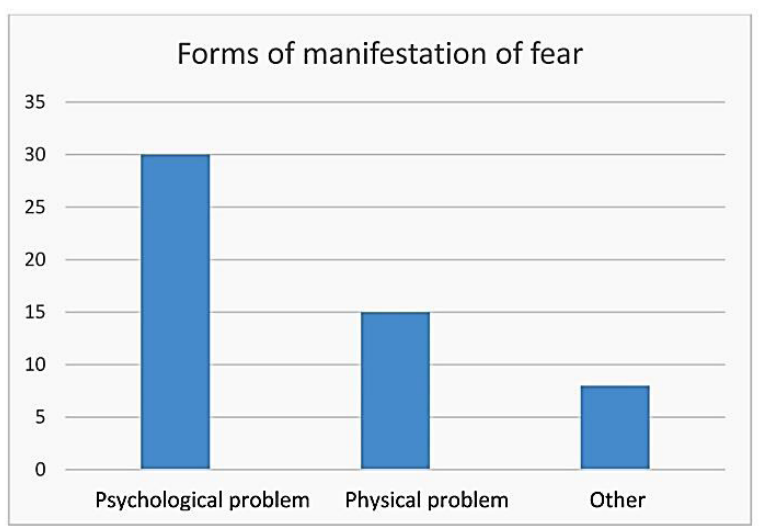

Graph 2. Forms of manifestation of fear

To combat the fear of mathematics, as we see in Graph 3 , parents work through exercise with the child $18 \%$, then compulsory additional classes $14.6 \%$, through conversation $10 \%$ and more homework $5.6 \%$.

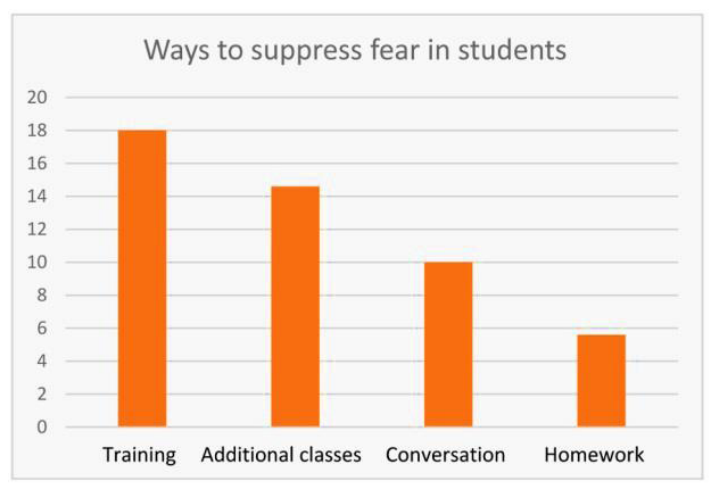

Graph 3. Ways of suppressing fear in students

demographic characteristics of the sample, and then the situations in which fear occurs and the way in which it manifests itself were analyzed. Table 9 shows the results of the t-test which examined the differences in the amount of fear of mathematics in students with regard to gender.

Table 9. $t$-test for differences in perception of fear of mathematics with respect to student gender

\begin{tabular}{cccccccc}
\hline Varijable & Group & N & M & SD & t-test & Df & p \\
\hline \multirow{2}{*}{ Gender } & Male & 46 & 2.78 & 1.41 & \multirow{2}{*}{.38} & 104 & -.41 \\
& Female & 58 & 2.69 & 1.35 & & & \\
\hline
\end{tabular}

The results show that there is no statistically significant difference between boys and girls in the amount of fear of math.
Subhypothesis 4: There is no statistically significant difference with respect to class in the amount of fear of mathematics.

Table 10. ANOVA a test for differences in the perception of fear of mathematics with respect to the class of students

\begin{tabular}{cccccccc}
\hline Variable & Group & N & M & SD & F & Df & p \\
\hline \multirow{6}{*}{ Class } & V & 21 & 2.62 & 1.50 & & & \\
& VI & 23 & 2.89 & 1.27 & 1.95 & 3,10 & \\
& VII & 20 & 2.55 & 1.34 & & & \\
& VIII & 20 & 2.85 & 1.28 & & \\
\hline
\end{tabular}


In Table 10 we see that there is no statistically significant difference in students with regard to grade, as in the case with regard to gender. Students also had the opportunity to write about the situations in which they develop a fear of mathematics and how it manifests itself. More than $70 \%$ of students answered these two questions, mostly students with a pronounced fear of math. The largest number of students, $45.19 \%$ cite oral examinations as the biggest source of fear, written examinations cause fear in $33.9 \%$ of students, fear of excessive parental expectations is in $18.3 \%$ of students, about $2.9 \%$ of students stated another situation, most often a raised tone of teachers during teaching.

\section{DISCUSSION}

Fear of mathematics has been recorded in all countries and all education systems. Mathematics is treated as a difficult subject and scientists are researching it more than other subjects. She is objectively a difficult object because her nature is pure abstraction. On the other hand, its structure is solid and collapses if only one segment is missing in it. The aim of this research was to investigate whether there is a fear ofmathematics, what are the causes of fear, whose basis is actually the main hypothesis of this research,

\section{CONCLUSION}

The teaching process is a series of joint activities of teachers and students during the class aimed at achieving learning outcomes that are defined in accordance with the Curriculum. There should be no room for fear in the teaching process. Students should not come to school under pressure or in fear, but should find ways to motivate themselves to work because of their personal progress and training for life. Parents and teachers help them with that. Achievements in mathematics are researched more than achievements in other subjects because mathematics is important for examining and comparing different educational systems. Because of this importance, we need to find ways to suppress students 'fear of math. In addition to motivation for work, students should be provided with support and encouragement. The main research hypothesis has been partially confirmed. It has been proven that there is a fear of mathematics in primary school subject teaching but there is no statistically significant difference between boys and girls. The way in which teachers suppress the fear of mathematics is conversation, while parents, in addition to talking to students, also mention work / exercise with the child, compulsory additional classes and more homework. Fear of mathematics manifests itself in two forms, metaphobia and anxiety. Rapid heart rate, tremors, nausea and fainting, headache, sweating, dry mouth, nervousness, panic attack, mental blockage, lack of concentration - all these are symptoms of metaphobia and anxiety. in what forms fear is manifested and what parents and teachers do to combat fear of mathematics in students. The main hypothesis of this research has been confirmed and it has been proven that there is a fear of mathematics in primary school subject teaching. By analyzing the results, we see that there is no statistically significant difference in the perception of fear of mathematics in students with regard to the demographic characteristics of the teacher sample. Research has shown that parents feel that children are afraid of math but no differences have been found in the perception of fear of math regardless of the gender of the parents. When it comes to the working status and age of parents, no differences were found in the perception of fear of mathematics in children. Regarding the education of parents, no differences were found in the perception of fear of mathematics in children. Students build on their parents and an equal amount of fear of math has been demonstrated regardless of the class that students attend. This is especially important, because the research sample consisted of fifth and sixth grade students. Sixth graders, who have just finished class, a teacher who teaches all subjects, possess the same amount of fear as ninth graders. This means that the fear of mathematics can also be found in the classroom, and that at the very beginning we need to find ways to combat this fear.

Nowadays, when most parents are employed, it is necessary to allocatequality time and work with the child. Communication with the child, and communication in the parent-school student relationship is very important to suppress the child's fear. Parents believe that compulsory additional classes for all students would greatly reduce the fear of math. The question is whether another math class would suppress the fear of math or whether it is necessary to change the ways of teaching. The teacher is not only a lecturer but a person who should direct the teaching process with his communication style in which students, with his support, research and build their knowledge. It is very important to establish proper communication with students and for students to feel that the teacher cares about his opinion. From the school year 2016/2017, teachers plan the Plan of written tests for both the first and the second semester, so that students are acquainted with the dates of tests, written tests and tests. Preparation classes for the written test should be done well and after that students should be motivated to work independently at home. The grade should motivate the student and the students are aware that during the year they create their own grade, that it is composed of several components and that it depends exclusively on themselves. On the other hand, it is necessary for teachers to constantly do self-evaluation of their work, to reexamine their role and make corrections to their work. This is the only way to achieve success in the educational process. 


\section{REFERENCES}

Arambasic, L., Vlahovic-Stetic, V., \& Severinac, A. (2005). Je li matematika bauk? Stavovi, uvjerenja i strah od matematike kod gimnazijalaca. Drustvena istrazivanja.

Arambasic, M. (1988). The Comparison of Some Empirical Functions of Growth Using Pond Snail Lymnaea Stagnalis $L$. as an Example, University of Belgrade

Agic, H., \& Resic, S. (2011). Matematika u ulozi izgradnje dobro obrazovane licnosti. Univerzitet $\mathrm{u}$ Tuzli. Uciteljski fakultet $\mathrm{u}$ Osijeku: 3. medunarodni znansrveni kolokvij Matematika i dijete. (http://www.seadresic.com).

Berce \& Puklek Lepuvscek (2011). Social anxiety, social acceptance and academic self-perceptions in high school students. Drustvena istrazivanja, 21(2) 405-419.

Halmi, A. (2003). Kvalitativna istrazivanja u drustvenim znanostima $i$ humanoj ekologiji. Pravni fakultet u Zagrebu.

Koludrovic, M. \& Radnic, I. (2013). Doprinos nekih osobnih i socijalnih cimbenika u objasnjenju skolskog uspjeha u ranoj adolescenciji. Pedagogijska istrazivanja. Portal of scientific journals of Croatia.

Milivojevic, Z. (2007). Psihopolis Institute, Edukacija, savetovanje i izdavastvo Novi Sad.

Muzic, V. (1986). Metodologija pedagoskog istrazivanja. Sarajevo: Svjetlost.

Muzic, V. (1999). Uvod u metodologiju istrazivanja odgoja $i$ obrazovanja. Zagreb: Educa.

Petz, B. (1992). Psihologijski rjecnik. Zagreb: Prosvjeta, p. 516.
Printer, J. Petrovic, N., Sotirovic, V., \& Lipovac, D. (1996). Metodika nastave matematike. Novi Sad.

Vujevic, M. (2006). Uvodenje u znanstveni rad u podrucju drustvenih znanosti. Zagreb: Skolska knjiga.

Read and downloaded from the following websites (04.11.-

21.12.2020.)

- http://mdtv.vpts.edu.rs/fajlovi/multimedija $\% 20$ preformatirana.pdf (Accessed 04.12.2020.)

- https://web.math.pmf.unizg.hr/nastava/metodika/materijali. php (Accessed 04.12.2020.)

- https://web.math.pmf.unizg.hr/nastava/metodika/ materijali/mnm3-nastavni_sat_matematike.pdf (Accessed 17.12.2020.).

- https://web.math.pmf.unizg.hr/nastava/metodika/materijali/ priprema.pdf (Accessed 03.01.2021.)

- $\quad$ https://www.slideshare.net/gordanadivic/povijestmatematike-history-of-math (Accessed 03.01.2021.)

- http://matematika.edu.rs/deca-koja-su-dobra-u-matematicibice-uspesnija-u-zivotu/ (Accessed 20.01.2021.)

- http://portal.skola.ba/start/Desktopdefault. aspx?tabid=117\&id=3997 (Accessed 20.01.2021.)

- https://prijatelj.weebly.com/uploads/1/2/9/7/12970621/ saradnja-porodice-i-kole-kao-faktor-prevencije-neuspehauenika.pdf (Accessed 20.01.2021.)

- http://www.istrazime.com/skolska-psihologija/strah-odskole/ (Accessed 28.01.2021.) 